UDC 930

\title{
CONTRIBUTION OF RESEARCHERS OF ROSTOV STATE MEDICAL UNIVERSITY TO HEALTH DEVELOPMENT OF BLACK SEA REGION
}

\author{
N. Drobotya, E.Chaplygina, O. Kamalova, E. Sklyarova \\ Rostov State Medical University. Rostov-on-Don, Russian Federation \\ science-almanac@mail.ru
}

For the first time consideredcontribution of scientists and doctors of Don region-K. S. Agadzhanyants,Z.N. Grzhebin, M.M. Gardashyan, P.P. Kovalenko, who were working at Rostov State Medical University andmade a contribution in development of medicine and health science of different Black Sea regions - Crimea, Turkey, Georgia, Romania, Bulgaria. Obtaining of knowledge and experience in medical activity, they were working and teaching not only inWarsaw and Don universities, but also in Sophia and Constantinopolitan universities, defended Crimea and Sevastopol during the Great Patriotic War.AfterRussian revolution in 1917 psychiatrist, neurologist, professor, doctor of medicine, graduate of the medical faculty of the Imperial Military Medical Academy of St. Petersburg K. S. Aghajanyants emigrated to Turkey for reasons of policy. Student of V. Bekhterev participated in the IX Pirogov Congress with report on the role of psychotherapy in dermatology, trained in Lisbon, Berlin, was a consultant on nerve diseases of the Southern (Caucasian) Front, worked in the Red Cross, taught at University of Constantinople and Sofia University. Doctor of Medical Sciences, Professor Z.N. Grzhebin was known in the USSR as a dermatovenereologist, he worked in Rostov-on-Don, Sochi, and Crimea. A graduate of the medical faculty of Kazan University, during the First World War, he as K.S. Aghajanyants, was on the Caucasian front, trained in Berlin. Professor Z.N. Grzhebin was a member of the board of the All-Union Society of Dermatovenerologists, dealt with problems of syphilis, skin lesions with poisonous substances, and the treatment of skin diseases in resort of Sochi-Matsesta. He took part in work of the expert commissions of the Ministry of Health of the USSR, held the posts of the dean and deputy director of Rostov Medical Institute, was head of the dermatological clinic and scientific part of the scientific research balneological institute of Sochi. Together with him worked native of present-day Turkey, the director of the Rostov Medical Institute M.M. Gardashian, whose fate was still classified in the state archives of Russia and the Rostov region after unreasonable political repression. Having headed work of Rostov Medical Institute, while holding the post of director, as well as an associate professor of the department of surgery faculty, in 1936 under his leadership a number of students of the "Fiery Release" of 1941 who during the Great Patriotic War rendered medical assistance to inhabitants of Crimea, defending Sevastopol, Rostov-on-Don, Stavropol, Novorossiysk. P.P. Kovalenko, graduate of the Fiery Release, after the war, headed the Department of General Surgery, became a Rector of Rostov Medical Institute, was first in the USSR to organize a regional tissue bank that provided donor tissues to the hospitals of Crimea and the North Caucasus, and represented the USSR in Romania in exchange of experience.Studies of the fate of doctors and Don scientists who made a significant contribution to the development of medicine and health in the regions of the Black Sea region are interdisciplinary and international. They reflect the development of the internal and foreign policy of the USSR, the difficult period of political repression, forced emigration, and the exchange of medical experience of the universities of Black Sea region.

Key words:Rostov State Medical University, Warsaw University, Sofia University, Constantinople University.

The history of medicine and health in Don region, as well as Rostov State Medical University, are inextricably connected with names of scientists and teachers who have contributed in different years to development of medicine and public health in various areas of Black Sea region. However, in scientific historical studies this problem has not yet received due attention and is being investigated for the first time.The fate of professor, doctor of medicine KarapetSargisovichAgajhanyants (1876-1955) was not simple. After the October Revolution of 1917 and Civil War in 1920, he emigrated to Tiflis for political reasons, and then to Turkey. This became a factor which determined for many years the silence of scientific research about its contribution to the development of medicine on the 
Don and Black Sea region. K.S. Agadzhanyants-was a psychiatrist, neurologist, neuroanatom, professor, doctor of medicine, a graduate of medical faculty of the Imperial Military Medical Academy of St. Petersburg, he was born and raised in Tiflis. Then in St. Petersburg he became a student, and later one of the associates of V.M.Bekhterev, whocreated a new higher educational institution in 1903 - Psycho-Neurological Institute. K.S. Aghajanyants was left for a contest at the Department of Soul and Nervous Diseases of the Imperial Military Medical Academy of St. Petersburg to improve medical activities.In 1904 he participated in IX Pirogov Congress with report on role of psychotherapy in dermatology [1, p. 404]. In 1906, he was "sent abroad for eight months with the highest permission to improve in sciences and participate in the 15th International Medical Congress in Lisbon" [4]. In 1910, K.S. Agadzhanyantswas already on probation in Berlin under the guidance of the German neurologist L. Jacobson, studying complex course of neuroanatomy. In 1911 K.S. Agadzhanyants was appointed as "head of the second physiotherapy unit for neurological patients" of St. Petersburglnstitute of Psychoneurology [9, p. 25], and read a course of lectures on nervous diseases at the institute. In 1913 - 1915 he already taught at the Department of Psychiatry of Warsaw University, where "it was the beginning of organization of museum with collections on the conducting paths of brain" [4]. In 1915 Warsaw University was evacuated to Rostov-on-Don, and in 1930 medical faculty of this university received the status of an independent institution in Rostov-on-Don.

During the First World War, after the evacuation of Warsaw University to Rostov-onDon, Professor K.S. Agadzhanyants became a consultant on the nervous diseases of the Southern (Caucasian) Front, worked in Red Cross, dealt with evacuation of mentally ill soldiers of the Caucasian Front. "In the Caucasus Mineral Waters as a consultant, he had an opportunity to provide assistance to the wounded ... In various cities of Russia (Tiflis, Rostov, Taganrog, etc.), he gave public lectures in order to propagate in the broad strata of society knowledge of nerve diseases, so little known" [4]. For his work in the Red Cross, K.S. Agadzhanyants was awarded with Order of St. Anna of the III degree, and for work in the Red Cross branch of Pyatigorsk -with a sign of the Red Cross.Being the first "head of department of nervous and mental illnesses" of the medical faculty of Don University, the professor headed the department in 1917-1920. By the end of 1917 an extension was built to the university clinic, which included an audience for lectures, which is preserved in the 21st century. The clinic was renamed as the Clinical Department of Mental and Nervous Diseases and City Psychiatric Department of the Mykolaiv City Hospital. He achieved the transfer of seven barracks and construction of a hydropathic clinic.

After October Revolution and Civil War in 1920, not accepting policy of the Bolsheviks, K.S. Agadzhanyants had to emigrate to Tiflis with white army, and then to Turkey. "In 1920, he left Rostov with leaving white parts" [11]. Settling in Turkey in the city of Constantinople, he already taught at the University of Constantinople in 1922, gave lectures. After the proclamation of the Turkish Republic in 1923, the university was reorganized. In 1922 1924 he lived and worked in Bulgaria. There K.S. Aghajanyants became a professor at the Faculty of Law at Sofia University [13]. The medical faculty of this university was established in 1917, and - veterinary in 1923. In 1929 at the Sofia University for the first time doctoral dissertations began to be defended. But K.S. Agadzhanyants emigrated from Bulgaria to France in 1924, where in 1928 he defended his doctoral dissertation in Sorbonne.

Employees of Rostov Medical University in the XXI century with respect mentioned Professor K.S. Aghajanyanets "After nationalization of our house, the last third floor was transferred to the jurisdiction of the former Warsaw University. Initially, the head of Department of Nervous and Mental Diseases KarapetSargisovichAgadzhanyants settled here, who is a bright personality, very professional. After his emigration abroad in 1920, the floor was divided into two unequal parts "[21, p. 171]. In 1937 - 1948 in the period of Stalinist repression in the USSR K.S. Aghajanyants was a chairman and then honorary 
chairman of Society of Russian Physicians named after Mechnikov in France. In 1931 1934 he worked at Russian dispensary of the Red Cross in Paris. He was married, "had three children" [4]. In 1950 he was elected as a chairman of the Union of Russian Armenians in France.

Scientific works of Aghajanyants K.S., dedicated to the structure and activity of human brain, mental and nervous diseases, were translated into several languages. His name stands among outstanding psychiatrists of the world, such as V.M. Bekhterev, A.I. Klimentovsky, M.Yu. Lakhtin, E.V. Pelican, A.I. Sikorsky, A.A. Tokarsky, S.I. Steinberg, D. Friedman, who studied the main types of group pathopsychological manifestations.Deputy Director for Academic Affairs, Doctor of Medical Sciences, Professor GrzhebinZinovy Naumovich (1893 - 1961) was known in the USSR as a dermatovenereologist, working in Rostov-on-Don, Sochi, Crimea. He graduated from the medical faculty of Kazan University (graduated in 1916) during the First World War as well as K.S. Aghajanyants, was on the Caucasian front, holding the post of regimental doctor, and then doctor of the military hospital. In 1923, Z.N.Grzhebin defended his thesis for a doctorate in medicine, and by decision of the People's Commissariat for Education of the Russian Federation in 1925 he was approved in the title of professor. Then he worked at Moscow State Venereology Institute. Later he became an author of a number of scientific papers published in various journals of the USSR. He pointed out that "strict isolation, treatment and early diagnosis - this is the basis on which the rational struggle against leprosy rests. As many years of experience proved, in the end result this will lead, if not to complete eradication, then, in any case, to a significant decrease in leprosy " [5, p. 137].

Z.N.Grzhebin was fluent in German and French. And in 1927, (as well as K.S.Agadzhanyants) was sent to Berlin for a scientific internship. He worked for a several months in a famous clinic of Rudolf Virchow. In 1930, he was a delegate to the USSR at International Congress of Dermatologists in Copenhagen (Denmark). In 1931 - 1941he became a professor of Department of Dermatovenereology of Rostov Medical Institute, heading department and clinic of skin and venereal diseases after retired P.V. Nikolsky. In 1934 he was awarded with doctorate in medical sciences. Professor Z.N. Grzhebin was a member of the board of the All-Union Society of Dermatovenerologists, dealt with the problems of syphilis [7], diagnosed skin lesions with poisonous substances [6], and repeatedly participated in work expert commissions under the Ministry of Health of the USSR. He was awarded with "Excellent worker of public health" badge, medal "For the Victory over Germany". For a number of years he held the posts of dean, deputy director of Rostov Medical Institute, supported the idea of creating a leprosarium in Don region.

From the first days of the Great Patriotic War, Professor Z.N. Grzhebin volunteered for the front and was appointed consultant-toxicologist of the 50th Army of the Bryansk Front. At the end of October 1941, with a group of ambulance workers, the front was surrounded and was in a prison camp in Korachi. Among the group of doctors he was sent to work as a doctor in the Gomel hospital. Acquainted with the doctors of the hospital, connected with the underground, he joined the anti-fascist struggle. With the help of the underground workers, in July 1943, an escapade of a group of captive medical scientists was organized, among them Professor Z.N. Grzhebin. After escaping from captivity, he became a doctor of partisan detachment. In 1943 - 1944 years. Passed a special examination in Moscow and from December 1944 the professor was sent to the position of only an assistant to the Rostov Medical Institute.

In July 1945, he was appointed to post of head of dermatological clinic, as well as head of the scientific part of scientific-research balneological institute in Sochi. During this period, he dealt with problems of treating skin diseases in resort of Sochi-Matsesta [8]. Then Professor Z.N.Grzhebin lived in Odessa and Crimea. He died in Sevastopol on August 14, 1961.The fate of the director of the Rostov Medical Institute M.M. Gardashian 
(1894 - 1938) was still classified in the state archives of Russia and Rostov region, after he was unreasonably repressed. Employees of the NKVD seized all his photographs and scientific works in libraries and archives. This was a natural phenomenon in the USSR for all scientists illegally arrested during the Stalinist repressions.

He was born in the city of Van, which only in 1923 according to the Treaty of Lausanne passed under the rule of Turkey. Therefore, in 1937, during his arrest in a case that was preserved in special register of Rostov-on-Don, it was erroneously written "was born in the city of Van (Turkey)". He received medical education in Georgia, enrolled in 1917 at the Medical Faculty of the University of Tiflis. In 1922 he graduated from the "Medical Faculty of Moscow University". In his personal file (No. 29618) it was stated: "The doctor since 1922". After graduation, he was sent to clinical residency at the I Moscow State University to the Department of Faculty Surgery. In 1925 - 1928 he worked as a "hospital resident and clinical assistant at the Moscow Botkin Hospital" [14, p. 79]. In 1928 - 1931 "He became the People's Health Commissioner of Armenia"[17, p.1209].

In 1935 - 1937 he "headed the work of Rostov Medical Institute, holding the post of director, as well as an assistant professor of department of faculty surgery" [14, p. 80]. It was in this period that in 1936, under his leadership, a famous set of first-year students of the "Fire Release" 1941 of the Rostov Medical Institute was implemented. The term "Fire issue" has forever entered the textbooks on the "History of Medicine", reflecting the contribution of faculty and graduate students of medical institutes who, in the years of Great Patriotic War, "voluntarily left for the front instead of the prom" [16]. The graduates of the "Fire Edition" of the Rostov Medical Institute in 1941, receiving "mobilization lists of the military commissariat, provided medical assistance to inhabitants of Crimea, Ukraine, Baltic States, defending Rostov-on-Don, Stavropol, Novorossiysk" [15, p. 19], becoming a pride of ALMA MATER. The name "Fiery Release" "became common for graduates of medical faculties of many cities of the USSR (Rostov-on-Don, Simferopol, Ulyanovsk, etc." [16, pp. 232, 18, p.73]. But in 1937, a year later after recruiting the "Fiery Release," M. M. Gardashian was arrested by the NKVD and biased because he "was an active participant in the Trotskyist terrorist organization." At the time of the illegal arrest he was 43. According to "the list of persons subject to the court of the military collegium of the Supreme Court USSR on June 10, 1938, the name of M.M.Gardashian was listed under No. 31 of the 189 repressed. "[2] The lists of persons subject to the court of the military collegium of the Supreme Court of the USSR were signed by IV Stalin IV and V.M. Molotov, M.M.Gardashian was shot on June 17, 1938. Today portrait of M.M.Gardashian hangs in the meeting room of the Academic Council of the Rostov State Medical University among the gallery of portraits of the leaders of the RostMU.Together with him the head of the AzovoChernomorskyKraisdravotdel - Donskoy Mark Grigoryevich (No. 50), doctor of medical sciences, professor, head Department of Occupational Hygiene (1932 - 1937) - PonizovskyMironSemenovich (No. 129), assistant professor of biological faculty of the Russian State University - Emil Nikolayevich Shpilrain (No. 182) and others were also shot. For the first time, the "Stalin lists" were published in 2002. By March 5, 2003 (on the 50th anniversary of the death of J.V. Stalin) an Internet version was published. In the era of Khrushchev's thaw on October 12, 1955, the verdict on the case of the surgeon M.M. Gardashian was abolished, the case was suspended "due to the absence of corpus delicti". This formulation was standard for all rehabilitated in the USSR.

Of particular respect is the graduate of the "Fiery Release" of 1941, Petr PetrovichKovalenko (1919 - 2008). He personally knew M.M. Gardashian, Z.N.Grzhebina while being a student. P.P. Kovalenko entered Rostov Medical Institute in 1936, led by these scientists. A graduate of the Fiery Release in 1941, a military surgeon, chairman of the trade union committee and rector of the Rostov Medical Institute, Honored Scientist of the RSFSR, corresponding member of the USSR Academy of Medical Sciences, MD, profes- 
sor became a pride of Rostov Medical Institute during Great Patriotic War. At the front, in military field conditions, yesterday's student carried out complicated operations on the intestines, heart, lungs, took part in the battles for the liberation of Crimea. Being the chief of the medical battalion in the battles for the liberation of Sevastopol for many days, without leaving operating room, he helped towounded. In 1942 - 1945 P.P. Kovalenko was the commander of the medical battalion in the rifle divisions of the Southern Front.

Since 1957, P.P. Kovalenko, who headed the Department of General Surgery, was one of the first in the USSR to organize a regional tissue bank at the Central State Clinical Hospital of Rostov-on-Don, which provides donated tissues to hospitals in Crimea and the North Caucasus. In the 1960s and 1970s, on the exchange of experience he represented the USSR in Romania. In 1959 - 1963, having passed all stages of career growth, "deservedly became the rector of Rostov Medical Institute. His disciples headed the surgical departments of Russian universities, as well as Syria, Bangladesh, Nepal, Nigeria, Lebanon, Cyprus, CIS countries (Georgia, Ukraine, Azerbaijan, Uzbekistan)." "P.P. Kovalenko was awarded with the Order of the Red Banner of Labor, the Patriotic War I and II degree, the Red Star, medals "For Military Merit", him. N.I. Pirogov » [19,P. 128 - 131].

Thus, it should be noted that the Rostov State Medical University is proud of its graduates and doctors, who in different years have contributed to the development of medicine and public health not only in the Don and the North Caucasus, but also in the development of medical science and public health in various regions of Black Sea coast - Crimea, Turkey, Georgia, Romania, Bulgaria. After the October Revolution, as well as during the years of political repression and Stalinism, they were forced to emigrate, Doctors of Don region, having received knowledge and experience of medical activities, worked and taught not only in the Warsaw and Don Universities, but also in Sofia and Constantinople universities, and also defended Crimea and Sevastopol during Great Patriotic War.

\section{Лumepamypa}

1. Агаджанянц К.С. Роль психотерапии в дерматологии // Русский врач. 1917. С. 404.

2. АП РФ, оп.24, дело 417 , лист 77.

3. ГАРО. Р. 46, опись 3, ед. хр. 9, св. 1.

4. ГАРО. Р.46, опись 1, ед. хр. 466, св.37.

5. Гржебин 3.Н. К вопросу ранней диагностики проказы // Венерология и дерматология. 1925. № 1.

6. Гржебин 3.Н. К клинике и диффреренциальной диагностике поражений кожи боевыми отравляющими веществами // Клиническая медицина. 1940. № 4.

7. Гржебин 3.Н. Клиническое значение серодиагностических реакций на сифилис // Вестник современной медицины. 1925. №1.

8. Гржебин 3.Н. Лечение кожных болезней на курорте Сочи-Мацеста // Вестник дерматологии и венерологии. 1948. № 2. С. 50 - 53.

9. История кафедры психиатрии Ростовского государственного медицинскогоуниверситета. От Императорского Варшавского университета до наших дней / Под. ред. А.О. Бухановского, В.И. Солдаткина. Ростов н/Д, 2014.

10. Камалова О.Н., Жолобова И.К. Основные тенденции и инновации в системе отечественного образования // Гуманитарные и социальные науки. 2016. № 1. C. $38-48$.

11. Новая психиатрия. 2010. № 6. 
12. Руденко А.М., Греков И.М., Камалова О.Н. Теоретико-методологические и фрилософские аспекты исследования творчества // Гуманитарные и социальные науки. 2014. № 4. С. 109-119.

13. Русская газета. 2012. 16 июля.

14. Склярова Е.К., Власова В.Н., КамаловаО.Н. М.М. Гардашьян (1894 -1938) директор Ростовского медицинского института // История медицины в собраниях архивов, библиотек и музеев: материалы III межрегиональной научнопрактической конференции. - Волгоград, Издательство ВолгГМУ, 2016.

15. Склярова Е.К., Гутиева М.А., Карташев А.В., Камалова О.Н. Вузы Северного Кавказа в годы Великой Отечественной войны. Ростов н/Д, 2016.

16. Склярова Е.К., Жаров Л.В., Камалова О.Н. История медицины: краткий курс. Ростов н/Д, 2015.

17. Склярова Е.К., Харламов Е.В. Основные этапы становления Ростовского государственного медицинского университета (к 100-летию высшего медицинского образования на Дону) // Научно-методический электронный журнал «Концепт». 2016. Т. 15.

18. Склярова Е.К., Чаплыгина Е.В., Камалова О.Н. Ростовский государственный медицинский университет в годы Великой Отечественной войны // Гуманитарные и социально-экономические науки. 2015. № 2 (81).

19. Склярова Е.К., Чаплыгина Е.В., Харламов Е.В., ЖаровЛ.В. От Варшавского университета до РостГМУ: история вуза в коллекциях библиотек и музеев Ростовского государственного медицинского университета (к 100-летию высшего медицинского образования на Дону) // История медицины в собраниях архивов, библиотек и музеев материалы II межрегиональной научнопрактической конференции, посвящённой 80-летию Волгоградского государственного медицинского университета. Волгоград, 2015.

20. Харламов Е.В., Склярова Е.К., Киселёва О.Ф., Сидоренко Ю.А. 50 лет с ALMA MATER. Ростов н/Д, 2015.

21. Kamalova O.N., Andramonova V.V. Networksociety: problemsofdevelopmentandnewformsofidentity // Актуальные проблемы науки: от теории к практике Материалы III Всероссийской научно-практической конференции. 2016.

22. Sklyarova E.K. Comparative aspects of scientific research of the urbanization problem // НаучныйальманахстранПричерноморья. 2016. № 2. http://sciencealmanac.ru

\section{References}

1. AgadzhanyantsK.S. Role ofpsychotherapeutics indermatology// Russkiyvrach. 1917.

2. AP RF, op. 24 , case 417, p. 77.

3. GARO. P. 46, list 3, item 9, sv. 1.

4. GARO. P.46, list 1, item 466, sv.37.

5. Grzhebin Z.N. On the question ofearly detection oflepra// Venereology and dermatology. 1925. № 1.

6. Grzhebin Z.N. On clinic and differential diagnostics ofdermhelminthiasis from war gas // Clinical medicine. 1940. No 4.

7. Grzhebin Z.N. Clinical relevance ofserodiagnostic reactions forsyphilis // Vestniksovremennoymedicini. 1925. No1.

8. Grzhebin Z.N. Treatment of dermatosis at resort Sochi-Matsesta // Vestnikdermatologiiivenerologii. 1948. No 2. 
9. History of Department of Psychiatry of Rostov State Medical University. From the Imperial University of Warsaw to the present day / Edited byA.O. Buhanovskiy, V.I. Soldatkina. Rostov-on-Don, 2014.

10. KamalovaO.N., Zholoboval.K. Main trends and innovations in system of national education // Gumanitarnyeisocialnyenauki. 2016. № 1. P. 38-48.

11. Novaya psihiatriya. 2010. No 6.

12. RudenkoA.M., Grekovl.M., KamalovaO.N. Theoretical, methodological and philosophical aspects of creativity research// Gumanitarnyeisocialnyenauki. 2014. No 4.

13. Russkayagazeta. 2012. $16^{\text {th }}$ of July.

14. SklyarovaE.K., Vlasova V.N., KamalovaO.N. M.M. Gardashyan (1894-1938) Director of Rostov Medical Institute // History of medicine in collections of archives, libraries and museums: materials of III interregional scientific-practical conference. - Volgograd, Publishing houseVolgGMU, 2016.

15. SklyarovaE.K., GutievaM.A., KartashevA.V., KamalovaO.N. The universities of the North Caucasus during Great Patriotic War. - Rostov-on-Don, 2016. - P. 19 - 20.

16. SklyarovaE.K., ZharovL.V., KamalovaO.N. Medicine history: short course. Rostovon-Don, 2015.

17. SklyarovaE.K., KharlamovE.V.The main stages in formation of Rostov State Medical University (to the 100th anniversary of higher medical education in Don region)// Scientific and methodical electronic journal «Concept». 2016. Vol. 15.

18. SklyarovaE.K., ChaplyginaE.V., KamalovaO. N. Rostov State Medical University during the Great Patriotic War // Gumanitarnyeisocialno-economicheskienauki. 2015. № 2 (81).

19. SklyarovaE.K., ChaplyginaE.V., Kharlamov E.V., ZharovL.V. From Warsaw University to RostGMU: History of the university in collections of libraries and museums of Rostov State Medical University (to the 100th anniversary of higher medical education in Don region) // History of medicine in collections of archives, libraries and museums materials of the II interregional scientific and practical conference dedicated to the 80th anniversary of Volgograd State Medical University. Volgograd, 2015.

20. Kharlamov E.V., SklyarovaE.K., KiselevaO.F., SidorenkoU.A. 50 yearsof ALMA MATER.Rostov-on-Don, 2015.

21. Kamalova O.N., Andramonova V.V. Network society: problems of development and new forms of identity // Actual problems of science: from theory to practice Materials of the III All-Russian Scientific and Practical Conference.2016.

22. Sklyarova E.K. Comparative aspects of scientific research of the urbanization problem// NauchnyialmanahstranPrichernomorya. 2016. № 2. http://sciencealmanac.ru

March, 23, 2017. 